\title{
バンドを使わない新しい抄紙薬品システム
}

\author{
BASF 社製紙薬品事業本部 W. J. アウホーン
}

\section{New Wet-end Chemicals for Low Alum System}

\author{
W. J. Auhorn \\ BASF AG Marketing Paper Dyes \& Process chemicals
}

\begin{abstract}
New concept on wet-end chemical system for neutral to pseud-neutral papermaking is proposed. To protect environment and preserve natural wood resources, conversion of present acid paper-making to low alum or alum free system must be established. Alum causes fiber strength to be lowered, thus makes recycling of paper more costly by using more chemical to recover strength. With the proposed wet-end chemicals, retention and drainage are improved by polyethyleneimine, as well as to control pitch problem and COD in effluent water. Rosin size will be replaced by effective polymer dispersions, which give improved press runnability and printability.
\end{abstract}

\section{紙パルプ産業の課題}

紙パルプ産業は木材資源，用水，及びエネルギー多 消費型の産業であり, 環境污染の発生源としても長年 に渡り注目されてきた業界である。これらの問題も 様々な技術開発により問題解決の成果が上がりつつあ る。古紙利用の拡大による木材資源の保存, 白水シス テムクローズド化による用水原単位の削減, 各種エネ ルギー回収システムの開発による省エネルギー，また 排水の活性污泥処理や無塩素漂白による環境污染削減 等が実施され，その効果も一㣽成果を上げているが, まだまだ全ての問題が解決されたとは言えない。

同時に近年，生産性を向上させる目的で様々な機械 設備の改善, 開発が行われ目覚ましい発展を遂げた。 ッインワイヤー， 八イブリッドフォーマ等の開発は抄 速 $1,000 \mathrm{~m} /$ 分以上を容易に達成させた。しかしながら 機械設備の発展の一方で, 抄紙薬品システムに関して は個々の薬品の開発は行われているが, 抄紙の調成か ら巻取りまでの全工程を統合した観点から薬品システ ムを開発した例は少ない。

BASF 社では古紙利用の拡大, 省エネルギー, 用水 削減および環境污染防止の観点から，バンドを殆ど使 わない擬中性から，バンドを使わない中性領域での抄 紙システムとそれに合致する一連の抄紙用薬品を提案 し，ヨーロッパ・北米の多数の工場で成功を収めてい る。本稿ではそれらの新コンセプトを紹介する。 バンドの役割

紙のインキのにじみを防ぐために古くからニカワ，
カゼイン，デンプン等のサイズ剤が使われて来た。二 カワを定着させる目的で, すでに 8 世紀頃からバンド が使われて来たが, 19 世紀初等にロジンとバンドによ るサイズ法が発明されると，バンドの使用が抄紙では 不可欠のものとなった。その後, ウェットエンドでの パルプの挙動, 紙層形成のメカニズム等が解明される に従い，バンドは単にロジンの定着剤としてだけでは なく, 他の役割が判明しバンド使用の効果が更に拡大 した。バンドのアルミニウムイオンは 3 価のカチオン であるた他のカチオン金属イオンに比べてカチオン 性が高いので, これが微細纎維やパルプ表面のアニオ ンと反応して歩留りを向上させる役割がある。また木 材中の抽出成分に由来するピッチトラブルを減少させ るためにもバンドが使われている。すなわちバンドの 役割とは：(1)ロジンサイズ剤の定着, (2微細繊維, 填 料の歩留向上，(3)ピッチトラブルの減少である。

ロジンの定着を目的に使われ始めたバンドであるが, ロジンを使わない系でもバンドは使われるようになり， その後, 酸性抄紙が製紙産業の主流となった。 バンドによる弊害

バンドの万能薬的な使用も，1960 年代に話題となっ た書籍の保存問題を契機にバンドの使用が問題視され るようになって来た。バンドあるいはアルミニウムイ オンが紙の劣化を促進することは良く知られた事実で ある。図 1 にその代表的な例を示す。未晒クラフトパ ルプを各種薬品で $\mathrm{pH}$ を調整して抄紙した場合の引張 強さを比較してある。塩酸や硫酸で酸性条件にした場 


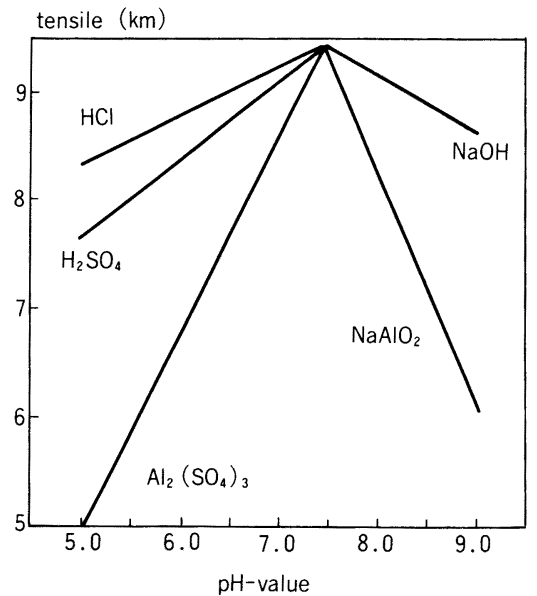

図 1 各種薬品で $\mathrm{pH}$ 調整して抄紙した紙の裂断 長 (紙料はUKP)

合よりも，硫酸アルミニウムを使って $\mathrm{pH}$ を調整した 場合の方が強度低下が著しい。このことから硫酸根の 影響よりはアルミニウムイオンが劣化におよぼす影響 が大きいことが分かる。またアルカリ性領域でも紙力 は低下する。すなわち紙力を維持するためには $\mathrm{pH}$ を 調整せず，得られたパルプをそのままで使うのが最も 良いことになる。更に古紙としてリサイクルした場合 の抄紙 $\mathrm{pH}$ と紙力の関係を図 2 に示す。上の 2 本の曲 線はカレンダー掛けなしでリサイクルした場合の $\mathrm{pH}=4.5$ および 7 のきの紙力（相対引裂強さで表 示）の低下を示しているが, 6 回のリサイクル後でも $80 \%$ 以上の紙力が維持されている。しかしながら, 力 レンダー掛けをした場合は（下の 2 本の曲線）紙力の 低下が著しく, 特にバンドを $5 \%$ 添加した $\mathrm{pH}=4.5$ の

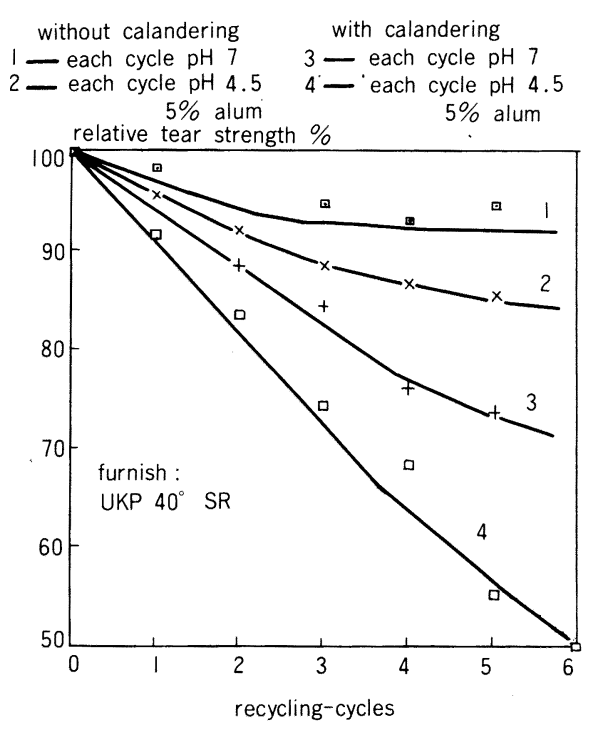

図 2 リサイクル回数と相対引裂強さの関係（紙 料はフリーネス $\left.40^{\circ} \mathrm{SR} の \mathrm{UKP}\right)$

場合では, 6 回目のリサイクルで紙力は約半分にまで 低下する。

古紙の利用率の拡大は古紙の選別を困難にし, 塗工 紙混入の増大につながる。従って古紙を有効利用する ためには塗工紙に含まれる顔料も十分に回収して製紙 用原料として再利用することが望ましい。塗工顔料に 含まれる炭酸カルシュウムの回仪は酸性条件下では不 可能であり, 中性条件下で回収・抄紙しなければなら ない。現在の主要地域における製紙用原料の使用比率 を図 3 に示す。ヨーロッパでは填料の使用比率が高く, 特にドイッでは古紙に由来する堪料を命わせるとその

\begin{tabular}{|ll|}
\hline Chemical Pulp & Mechanical Pulp \\
Waste Paper & Filler \\
\hline
\end{tabular}

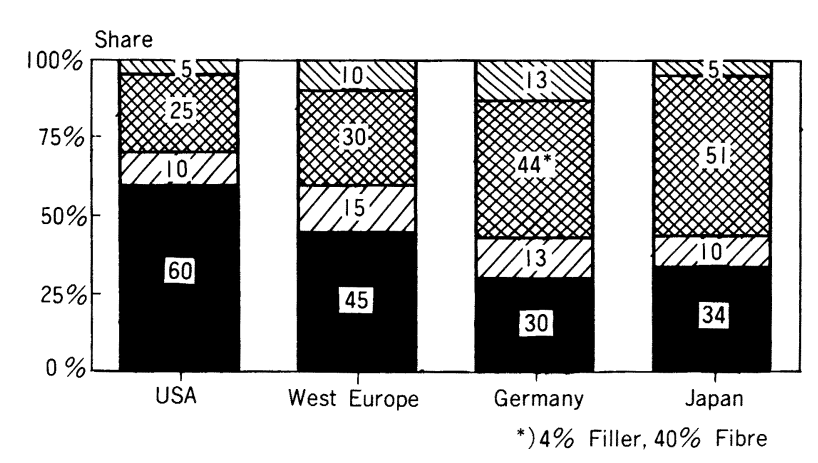

図 3 主要各地域での製紙原料使用比率 
使用比率は $17 \%$ にも達する。一方, 米国や日本では塡 料の使用率は $5 \%$ 程度である。

安価な塔料である炭酸カルシュウムを多量に使い, 古紙に由来する顔料も回收利用するためには, バンド を使わない中性抄紙システムが要求される。填料の利 用は原料コストの大幅な削減になる。

白水系中の硫酸根の存在は工場設備の腐蝕を増進さ せることとなる。その一例を表 1 に示す。ステンレス (SUS 304) でも徐々に腐蝕が進行する。コンクリート は全く抵抗がない。

バンドを使う事による問題点を挙げると：(1)紙力の 低下，(2)安体な炭酸カルシュウムが使えない, (3)塗工 古紙中の兏分の叫收不可, (4)設備の腐蝕促進である。

この様に環境保護の立場から古紙の利用率を更に上 げ，且つパルプ䋐維や填料（古紙からの回収もふくめ て）を有效に利用して行くためには, 酸性抄紙から脱 却してバンドなしの抄紙システムを確立する必要があ る。ちなみに主要齐国の中性化率を図 4 に示す。日本 における中性抄紙は紙・板紙合わせても15\%程度であ る。ヨーロッパではすでに半分以上の紙・板紙が中性 であり，図３に示す様に古紙と共に填料も回収利用さ れている。北米でも30\%以上に達しており中性化の傾 向はさらに促進されつつある。

中性抄紙（バンド不使用）系のウェットエンド化学

上述した様に硫酸アルミニウムはロジンサイズ剤の

表 1 硫酸バンドによる各種材質の腐蝕速度

\begin{tabular}{c|l}
\hline \multicolumn{1}{c|}{ 質 } & \multicolumn{1}{|c}{ 腐蝕速度 } \\
\hline 炭素鋼 & $1 \sim 10 \mathrm{~mm} /$ 年 \\
ステンレス & $0.1 \sim 1 \mathrm{~mm} /$ 年 \\
コンクリート & 抵抗なし \\
\hline
\end{tabular}

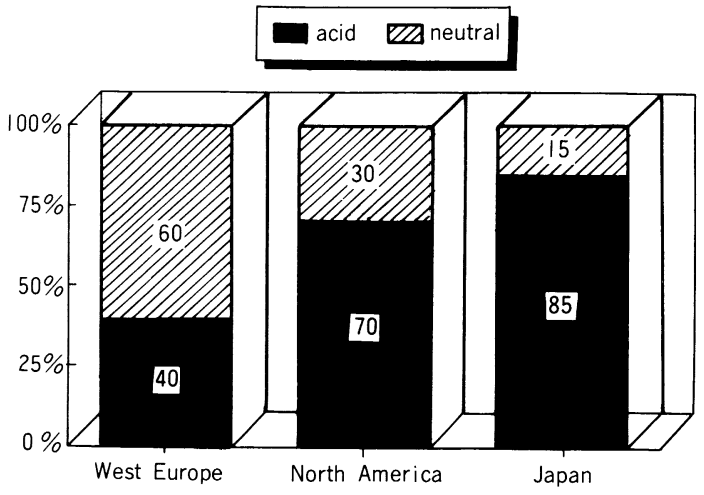

図 4 主要各地域での中性抄紙比率
定着に不可欠のものであると同時に紙力低下をもたら す。しかしながら，現在のウェットエンド化学は酸性 抄紙を主体に開発されたものであり，ポリアクリルア

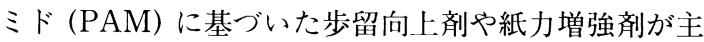
に使用されている。アルミニウムイオンの存在しない 系で抄紙するにはウェットエンド化学を見直す必要が ある。そのためには硫酸アルミニウム (バンド) の役 割を他の薬品で代替しなければならない。ロジンに代 わる中性系でのサイズ剤としては AKD ASA の様 な合成モノマーとラテックスと同様な特性を持つ合成 ポリマーがある。これらのサイズ剤の定着にはバンド を必要とはしない。

アルミニウムイオンはその高いカチオン性のために, パルプや填料の歩留に寄与すると同時にピッチ等のア ニオン性有害物質の除去にも効果がある。これらの役 割はカチオン性の高い薬品で代替することができる。 その代表的な薬品はポリエチレンイミン (PEI) であ る。PEI は他のカチオン性薬品, 例えばカチオンでん ぷん，カチオン PAM 等に比較して非常に高いカチオ ン化度を持っている(図 5 参照)。しかもこのカチオン 性は幅広い $\mathrm{pH}$ 領域で維持されているために，酸性領 域のみならず，中性抄紙条件下でもその効果はほとん ど変わらない。

以下, 様々な薬品の作用を比較しながら PEI を核と した薬品システムの応用について述べる。

フロキュレーション（歩留と沪水性）

マシンの操業性からみるとパルプの歩留および沪水 性が重要であるが, 製造された紙の特性からみると地 合が最も基本的な因子となる。これらの特性を支配す るのはパルプや塡料が形成するフロックの量, 質, 状 態である。フロキュレーションの形態としてはその大 きさ, 形, 強さなどがあるが, 木モ凝集かへテロ凝集 の違いも重要である。PEIおよびPAMによるフロ

Charge density at $\mathrm{pH} 4.5$ (mequiv/g of active substance)

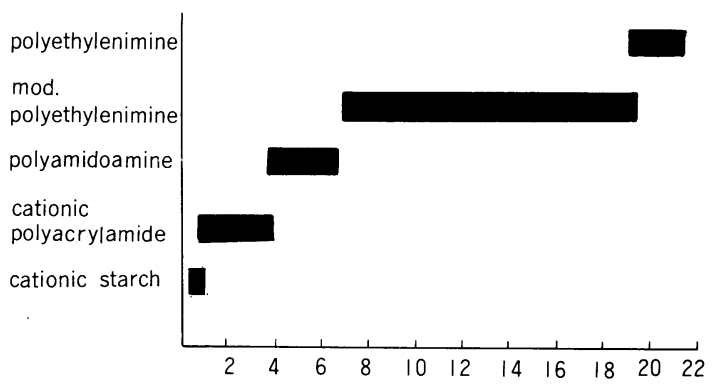

図 5 主要薬品のカチオン化度（ミリ当量/g) 
表 2 PEI およびPAMの凝集作用

\begin{tabular}{l|l|l}
\hline & \multicolumn{1}{|c|}{$\mathrm{PEI}$} & \multicolumn{1}{|c}{$\mathrm{PAM}$} \\
\hline 大きさ & 小さい & 大きい \\
堅さ & 柔らかい & 堅い \\
強さ & 弱 い & 強い \\
形 態 & ヘテロ凝集 & ホモ凝集 \\
主な結合 & 静電力 & 分子間力 \\
メカニズム & パッチモデル & 高分子架橋 \\
\hline
\end{tabular}

キュレーションの作用の違いを表 2 に示す。

このような違いはPEI および PAMの基本特性に 由来する。PEI は 3 次元構造を持った小さな球状の粒 子でありカチオン度が非常に高い。これと対照的に PAM は長鎖状の高分子で水中では十分に伸長されて いるがカチオン度は低い。

PAM をパルプ調成工程で添加すると微細繊維や填 料が凝集し強固なフロックを形成するのでワンパスリ テンション (OPR) は上がるが, フロックが大きいた めに地合いは良くない。PEIを使うと微細繊維や填料 はパルプ繊維表面にへテロ凝集するので形成されるフ ロックも小さく凝集力も PAMの場合よりは弱い。し たがって沪水性は上がるが歩留はあまり上がらない。 しかしフロックは小さいので地合は改善される。

PEI および PAM による凝集は様々な結合様式が作 用しており，特定の結合様式のみでなくそれらの統合 である。大概の配分は表 3 の通りである。

すなわち PEI は静電的引力による結合が主体であ り結合力も強い。一方, PAM は主に水素結合により凝 集するので結合力も弱く剪断応力の影響を受けやすい。 さらにPEIのカチオン化度はほとんど $\mathrm{pH}$ に影響さ れないので, 酸性領域から中性領域まで広い範囲でそ の効果が維持されるが，PAM の場合は酸性領域での みその効力を発揮する。

抄紙工程の基本操作の大部分は脱水と乾燥丁程であ る。従つて脱水・乾燥の効率を高めることは直ちに省 エネルギーに慗がる。PEI および PAM のプレスT程 での脱水効果の比較を表 4 に示す。プレス後での水分

表 3 PEI と PAMの結合エネルギーと結合比率

\begin{tabular}{l|c|c|c}
\hline \multicolumn{1}{c|}{ 結 合 形態 } & $\begin{array}{c}\text { 結合エネルギー } \\
(\mathrm{kcal} / \mathrm{mol})\end{array}$ & $\begin{array}{c}\text { PEI } \\
(\%)\end{array}$ & $\begin{array}{c}\text { PAM } \\
(\%)\end{array}$ \\
\hline イオン結合 & $10 \sim 30$ & 50 & 20 \\
水素 結 合 & $4 \sim 6$ & 40 & 60 \\
ファンデルワールスカ & $0.5 \sim 2$ & 10 & 20 \\
\hline
\end{tabular}

表 4 歩留问上凨によるワイヤパート，プレス パートでの脱水率拉よび相対蒸気消費量

\begin{tabular}{|c|c|c|c|}
\hline & 無添加 & PEI & PAM \\
\hline ワイヤパート後の水分 $(\%)$ & 80 & 79 & 78 \\
\hline プレスパート後の水分 $(\%)$ & 57 & 55 & 56 \\
\hline 蒸気使用量 （ton/ton） & 1.40 & 1.20 & 1.30 \\
\hline 生 産 量 & 100 & 110 & 104 \\
\hline
\end{tabular}

量が $1 \%$ 違うことによりドライヤパートでの蒸気使用 量は約 10\%節約され, その結果, 生:産性の占.|に:大き く奇少することになる。

このようにPEI と PAM はそれぞれ特徴があり，ど ちらが効果的に作用するかはマシンの操業条件によっ て異なる。両方の艮さを间時に満足させる方法として PEI とアニオン性 PAM あるいは非イオン性 PAM の 組み合わせや，アニオン/カチオン PAMの組み合わ せ等が提案されている。しかしこれらの方法は2ヶ所 添加となり, 添加量の調整など操栄が複雑になるため 広範囲には使用されていない。この䦌題を解決したの がBASF 社が新しく導入した「ポリミックス」システ ムである。このシステムではPEI とカチオン PAM を 闹時に単一添加装置で抄紙䑪成厂程の適切な筒所に添 加する事により歩留と沪水性の晌.:を達成させる方法 である。しかもこの「ポリミックス」システムは酸性 抄紙から中性抄紙のいず祅の操業条作でも適用するこ とができる。

\section{有害物質の除去}

紙の原料となる紙料中に混人してくる大きな哄物は スクリーンやクリーナで除去できるが，コロイド状の 粒子や溶解している物質の除去は闲難である。それら は木材成分に由来する樹脂分やリグニン, 汁紙に由来 するホワイトピッチや粘着物筫，あるいはデンプン等 の様々な添加覍品で木定着なものなどである。これら の有害物質はアニオン性のものが人部分であるので, それらを抄紙系の外に取り惊なないはカチオン性の 薬品が份效に作用する。

ピッチトラブルを解決する方法としては，もちろん バンドを添加することはよく知られたす法であり，夕 ルクのような表而エネルギーの大きき粉体に吸着させ る方法もある。純粋な PEI あるいは変性 PEI は公範进 なカチオン化度のものがあるので, 份害物質のタイプ や量に応じて, 㫨も效果のあるカチオン化度の PEI 選択することによりピッチトラブルを効果的に解決す ることができる。PEI 処理によるマシン门水中のビッ 千粒了の数をへマシトメー夕（顕微鏡血球計数板）で 
離解時の遊離インクと未剥離インク

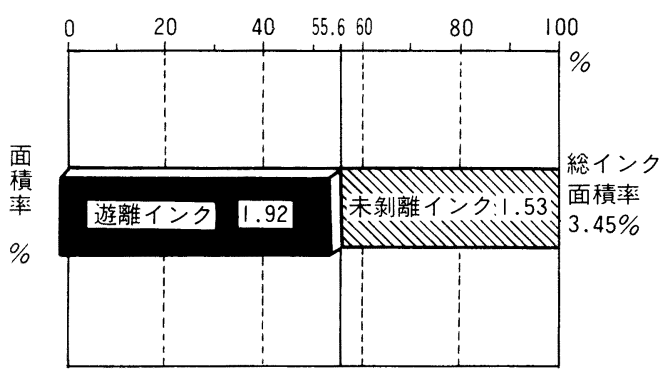

首都圈新聞古紙ベール物

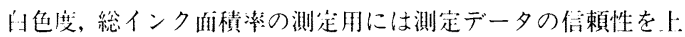
げるため, $3 \mathrm{~g}$ 相当の原料を $500 \mathrm{cc}$ に希翻し, 硫酸バンドを用い

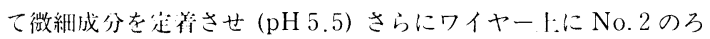
紙を教いて、微紐成分が逃げないようにして作成したハンドシー 卜を使用した。また，パルプそのものの门色度の测定や未剝離イ ンクの测啨には $5 \mathrm{~g}$ 相当の原料を 150 メッシュのふるいを用い で管食洗浮してから作成したハンドシートを使用した。
サイズ毎のインク面積比較

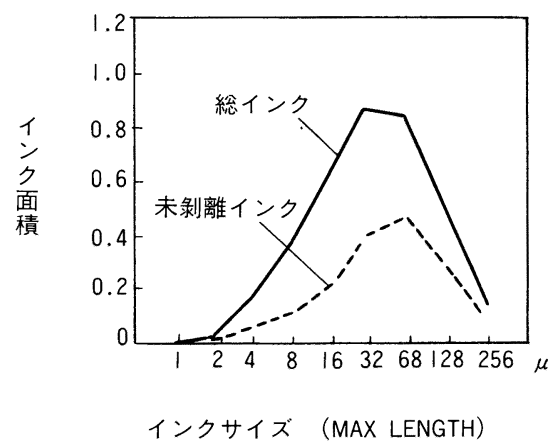

図 4 離解時の遊離インクと末剥離インク

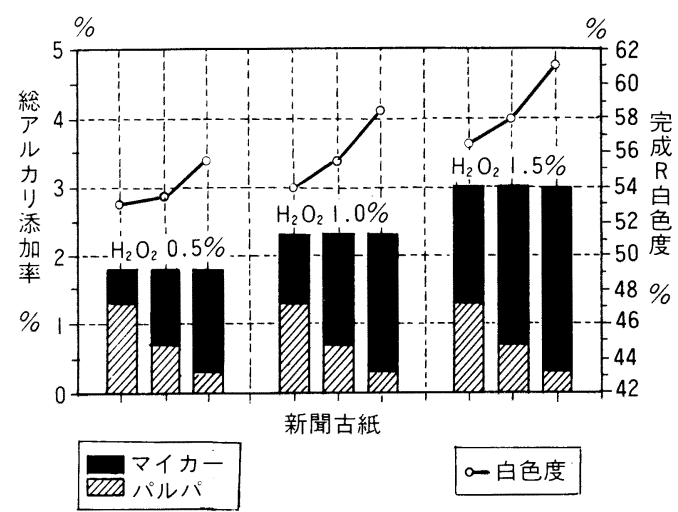

図 5 アルカリ添加比率と完成的色度

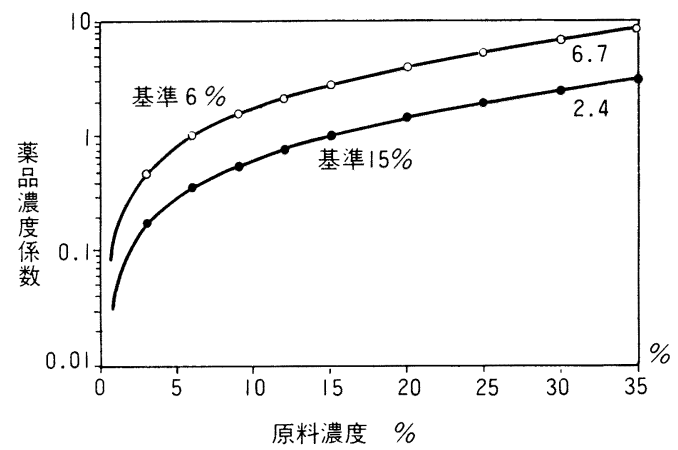

図 6 原料濃度と反応薬液濃度
(たとえば， $\mathrm{NaOH} \mathrm{0.1〜0.3 \% )。}$

一方, 低・中濃度ハイドラパルパ式離解の久点と言 われていな異物の細分化については図7に示すような ハイドラパージシステムや図 8 に示す高濃度微小ス リットスクリーンシステムによって解決された。

$50 \mathrm{~T} / \mathrm{D}$ 以下の小容量システムの場合は $9 \%$ バッチ 離解のミドコン (Middle Consistency) パルパとハイ ドラパージーIIIの組み合わせで 1 バッチ毎の異物をハ イドラパージ下部のドレーナへ直接ブローするが, 大 容量システムの場合は 4 6\%連続離解の D 型ハイド ラパルパとし，パルパ内に滞留する粗離解原料を直接 抜き出し, 30 ～ $40 \mathrm{~kW} / \mathrm{m}^{3}$ の特殊 D 型ケーシングを持 つハイドラパージーIIで補助離解・選別を行い紐状異 物, 粘着・フィルム状異物を粗大な状態で数分毎にセ レクトパージから排出し，パルパ内を常にクリーンに 保つ。

表 1 に示すようにハイドラパージーII，IIIは $21 / 24$ 型, 33/36 型の 2 機種, セレクトパージは 30 型, 45 型 の 2 種類を用意している。

このハイドラパージシステムによりパルパのノーブ ローが実現し, 省人化, パルパの能力アップ, 後丁程 の異物トラブルの解消等多くのメリットが生まれた。

また，高濃度（2.5３.5\%）で高レベルな精選が可 能な PSD/PSL ウルトラスクリーン（ディンプル／ レーマンシリンダ内蔵, $0.25 \sim 0.55 \mathrm{~mm}$ スロット幅) で後段の剝離・分散工程を通過する前に異物の除去を 完了させる。 
使われている。ロジンの定着にはバンドが必要である。 中性抄紙系ではロジンが使えないので，それに替わる サイズ剤として AKDや ASA の様な合成サイズ剤が 開発された。また酸性・中性を問わず両方の条件で使 用可能な高分子タイプのサイズ郕が開発されたことに より紙のサイズ方法が多様化した。

高分子サイズ剤は当初表面サイズ剤として開発され たものであるが，化学的変成によってカチオン化度を 変えることにより, 内添サイズ郕としても利用される 様になった。高分子として使われるものはアクリル酸 エステル, メタアクリル酸エステル, スチレン, アク リルニトリル等をべースにしてカチオン性助劑あるい はカチオン性分散剤でラテックス状にしたものである。 カチオン電荷をもっているので, それ自身でパルプ表 面に定着し, ドライヤーパートで加熱され，ポリマー が軟化し紙表面に拡がり疎水性膜を形成する。従って
マシン上で直ちにサイズ効果が発捰されるので，サイ ズ度のコントロールが㝘易である。 $\mathrm{pH}$ や紙料にも左 右されず, 貯蔵安定性も高いので操棠: に簡易化され る。

数種の紙料を用いて AKD およびアクリル系の高分 子サイズ剂を内添して抄紙した手漉紙のサイズ試験 (コッブ）結果を大々図 10 および図 11 に小すすAKD でサイズした場合，紙料が翼なるとサイズ発现効果が 異なり，上質紙では少量で效果が発揮されるが, GPや 古紙を含む場合は多量の AKD 必要とする。一方，高 分子サイズ剂は紙料の種類に全く関倸なく一定のサイ ズ効果を発揮するので, マシン操業、紙料の变動を考 虑する必要はなくなる。

更に高分子サイズ剤の特烄は, サイズ效果を達成す るのみならず, 紙力の向、に南献し, 特に表面強度が 上昇し，その結果として印刷適性が呚湆されることで

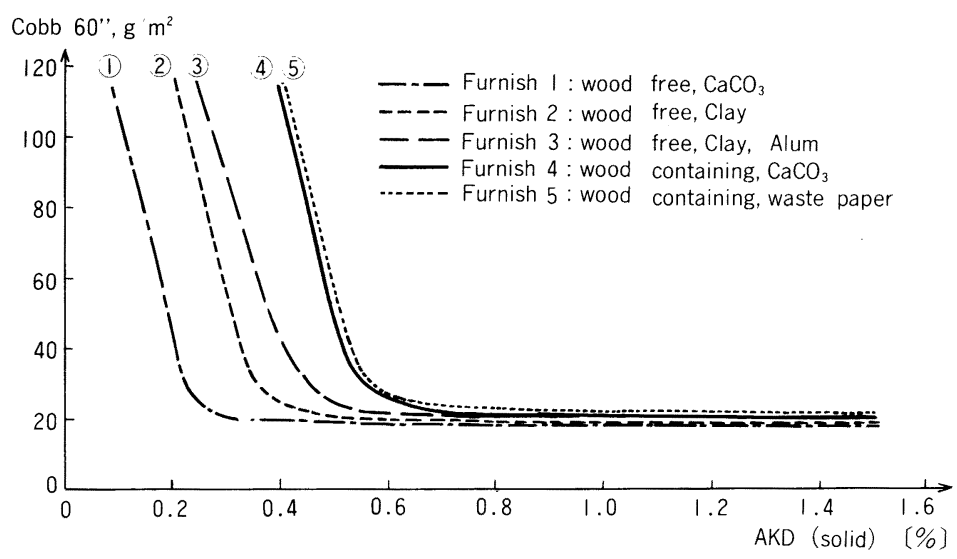

図 10 各種紙料に対する AKD サイズ剤の効果

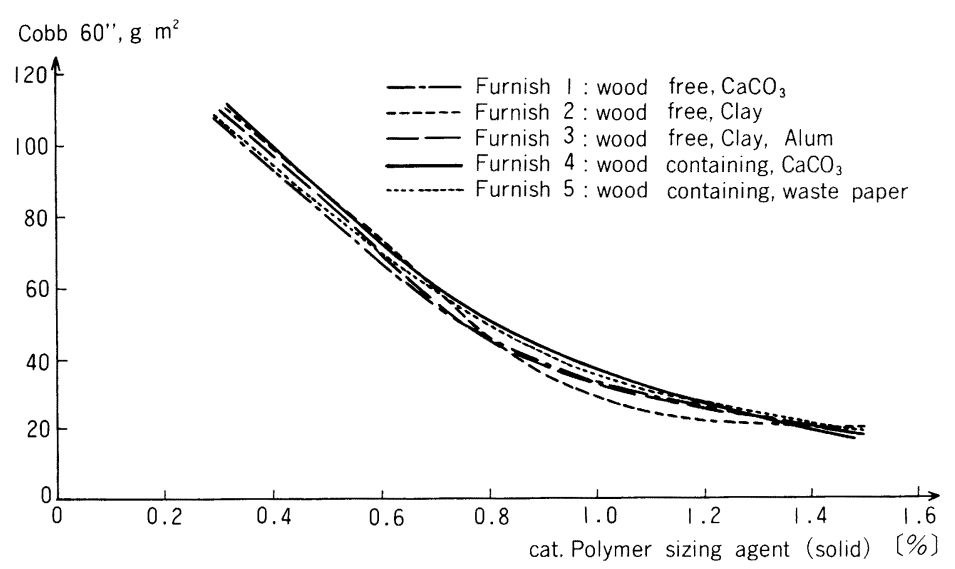

図 11 各種紙料に対する高分子サイズ剤の效果 
The surface strength of supercalandered gravure paper $60 \mathrm{~g} / \mathrm{m} 2$

IGT dry pick strength (top side)

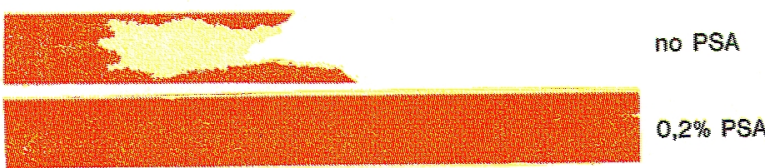

IGT wet pick strength (top side)

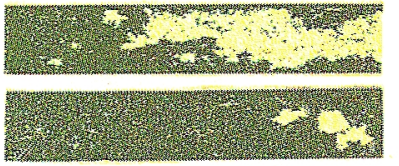

no PSA

[园 12 スーパーカレンダー維のプルーフバウ・オフ

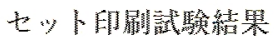

ある。一例として SC 紙のオフセット印刷試駼結果を 图 12 にनाओ

\section{空気含有量とマシン操業性および紙品質}

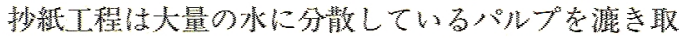

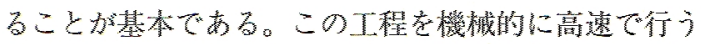
過程の中で水中にかなりの量の空気が小さな激となっ て取り込まれ操䔝上㧍よび紙品質上障害となる。パル

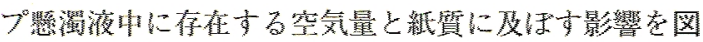

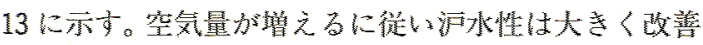
され，悢のポロシティーも增大寸る傾向にある。しが し一方では坪量がかずかに滅少することになり，裂断

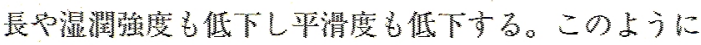
パルプウに溶在している空気は樣々な影響をおよぼす。 従って桑内の表面の泡を消すだけでなく溶存している 微細空気泡を效率的に除土する必瑟がある。

抄絟工程中で発生する液表面の泡を除去するには才 イルタイプの消泡咧が有效であるが, 系内に嚓解して

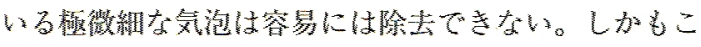

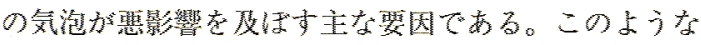
泡を除去するにはエマルションタイプの脱気剂が有效 であるエマルションは水服高ばやく分散して溶解

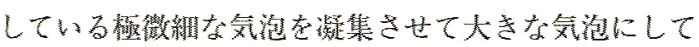
表面に浮遊させた後，泡を破裂させて除去する。

またエマルションタイプの特雅はサイズ剂の效果を 新げないので，ロシンサイズや他のサイズ剂を有效に 使用することが可能になる。

\section{新コンセプトの姴点}

地球に優しい紙作りを目指す製綎産業にとって原料

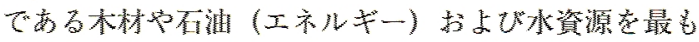
有效に利用子る力法を傕立することガ求められている。

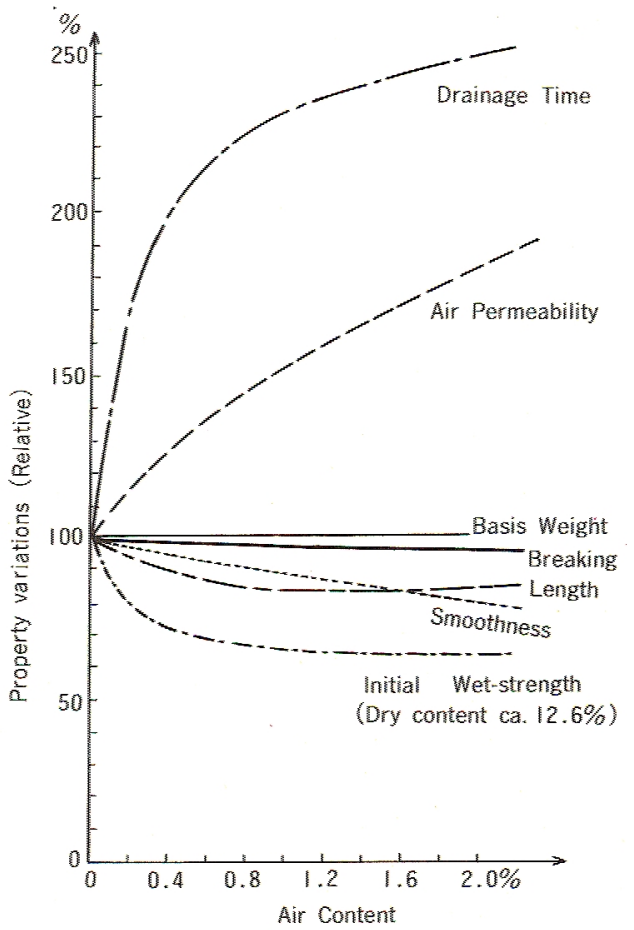

图 13 紙品筫に伋ぼ丟気量の影響

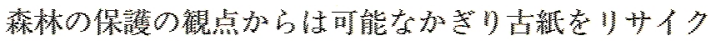
ルし，伐採する木材を最小限にしなければならない。 エネルギーや用水の原単值老削娍するには墑场な薬品 システムの選択が重要である。

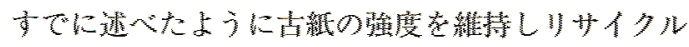
をより效果的に行うには中性抄縟が有利となる。山性

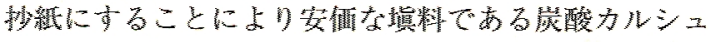


表 5 現行酸性抄紙システムと“新コンセプト”の使用薬品比較

\begin{tabular}{|c|c|c|}
\hline & $\begin{array}{l}\text { 従 } \quad \text { 来 } \quad \text { 法 } \\
\text { 酸性抄紙, } \mathrm{pH}=4.5\end{array}$ & $\begin{array}{l}\text { 新コンセプト } \\
\text { 中性抄紙, } \mathrm{pH}=7\end{array}$ \\
\hline $\begin{array}{l}\text { マシン操業性 } \\
\text { ピッチ・付着物コントロール } \\
\text { サイズ剤 } \\
\text { 紙力増強剤 } \\
\text { 消 泡 剤 } \\
\text { 歩留・沪水剂 } \\
\text { 排水処理 }\end{array}$ & $\begin{array}{l}\text { バンド } \\
\text { バンド } \\
\text { ロジン+バンド } \\
\text { PAM 系 } \\
\text { アフラニール } \\
\mathrm{PAM+バンド} \\
\mathrm{PAM+バンド}\end{array}$ & $\begin{array}{l}\text { ポリミン } \\
\text { ポリミンノカチオファスト } \\
\text { バリプラスト } \\
\text { PAM 系 (少量) } \\
\text { アフラニール } \\
\text { ポリミン ( + PAM) } \\
\text { ポリミン }\end{array}$ \\
\hline
\end{tabular}

ウムの利用が可能になる。古紙の回収が進むと古紙中 に塗工紙の混入が増大することになる。塗工層にはク レー以外に多量の炭酸カルシウムが使われている。こ れらをパルプと同様に回収し製紙原料として使うため には系を中性化する必要がある。現にヨーロッパでは 古紙中の填料もほとんど完全に回収しているので，新 聞用紙の灰分量も 8 12\%と非常に高い。しかし日本 では 2〜 4\%と低い水準にある。

従来の酸性抄紙系で一般に使用されている薬品シス テムと本稿で提案したバンドを使わない新しいコンセ プトに基ずく中性抄紙系での使用薬品を表 5 に列記し た。従来の酸性抄紙系ではバンドを主体とした薬品構 成になっているが，中性抄紙系ではポリミンを主体に し高分子サイズ剤を使用する新しいコンセプトに基ず く薬品システムである。ポリミンは高カチオン性のた めにパルプ繊維や塡料との親和性が非常に高く, 重金 属や芳香族ハロゲン化物も含まれていないので，排水 やスラッジへの水質污濁負荷も全くない。更にこの新 コンセプトによる抄紙システムによって達成される效 果を表 6 に列記した。従来のロジン・バンド系と比べ ると全薬品コストははある程度高くなる傾向にあるが, 生産性の増加を考虑すると全生産コストは安くなる。
表 6 “新コンセプト”によって得られる効果

\begin{tabular}{|c|c|}
\hline & 新コンセプトの利点 \\
\hline 1. 生産性 & $5 \sim 10 \%$ 向上. \\
\hline 2. 紙品質 & 紙力10～20\%堌加 \\
\hline & 紙料コストの削減（古紙, 垻料) \\
\hline 3. 操業性 & 洗浄間隔の延長 \\
\hline 4. 排水処理 & SS $50 \sim 90 \%$ 削減 \\
\hline & COD $30 \sim 50 \%$ 削減 \\
\hline 5. 清水使用量 & 大幅削減 \\
\hline 6. 全薬品コスト & 0 30\%増加 \\
\hline 7. 全製造コスト & 5 10\%減少 \\
\hline
\end{tabular}

抄紙機の機械的改善による生産性の向上.はほとんど 完成の域に達しており，今後の進歩は楽品が寄与する 所が大きい時代となりつつある。BASF 社は製紙会社 との長年の経験から, 複雑な物理・化学的な作用に関 するノウハウをもとに, 倜々の工場に対して適合した 薬品システムを提供している。ここで提案した新コン セプトとは，中性抄紙あるいはバンドをほとんど使わ ない抄紙システムを確立することにより，より高品質 で且つ環境保全に貢献する薬品システムである。 